\title{
SW. AUGUSTYN A STAROŻYTNY DRAMAT TEATRALNY
}

w rozleglej $i$ wielokrotnie juz przebadanej literackiej spuściźnie św. Augustyna warto równiez prześledzić jego stosunek do starozytnego dramatu teatralnego. Przez tego rodzaju dramat rozumieć będziemy nie tyli:o tragedie 1 komedie, ale równiez ich pochodne - mim i pantomime, któro w okresie patrystycznym opanowały sceny teatralne. Zebrane ungi na ten temat sa tym bardziej golne zauwazenia, ze pochodzą od człowieka, który - swej młodości pasjonował się teatrem ${ }^{1}$, później jednak, podobnie jak wielu rzymskich moralistów 1 ogół 0jcow Kościoła, zajal zdecydowanie negatywne stanowisko wobec nspołczesnych sob1e widowisk teatralnych ${ }^{2}$, a tym samym w wzya stopniu 1 wobec dramatu starozytnego. Postawiony problem omówimy w trzech zasadniczych częściach: wiemszej, prezentowanej w obecnym ze-

1 Por. Confessiones III 2, 214 , CSEL 33, 44146 , tłum. Z. Kubiak /Sw. Augustyn, Hyznania, Harszawa 1982/, 34-35: "Bardzo mnie wtedy pociagały widowiska teatralne/spectacula theatrica/, bo były pełne obrazów mojej niedoli ... Wtedy w teatrach uczestniczyłem w radośc1 kochanków, gdy występnie radowali sie sobą, chociaz to sie tylko fikcyjnie rozgrywało na scenie".

2 Zaden chyba z ojców Kościoła nio zasypywał współczesnych sobie przedstawień teatralnych takiml inwektywami, jak to czynit Augustyn, głównie w "De c1vitate De1" II 27, 16-18. Potepia je tam $j$ ako "talium numinum placatio petulantissima Inpurissima inpudentissima nequissima inmundissima". Swoja krytyke w1dowisk teatralnych oparł w dużej mierze o IV księge "De republica Cycerona. Podkreslat głównie niemoralny mpływ teatru, którego przedstawienia określał jako "foedus" "De civitate VI 7, 74/, "turpis" /De c1vitate I, 32, 3; II 4,17 ; 20,30 ; IV 3,3 ; VI 6,$57 ; 7,2 ; 8,19$; VIII 5,13 ; 14,$58 ; 18,13 ; 27,45 ;$ XVIII 12, 62; De opere monachorum 20; De vera religlone 51, 100; Sermo 198, 3/, "dedecorus" /Epistola 138, 14/, "ludibris"/De c1vitate VI 9, 45; VIII 18,$18 ; 21,62 /$, "obscoenus" /De civitate II 4, 25; 6, 12; VI 7,$94 ; 8,47$; VII 27, 34; VIII 5, 12; 14, 14/. Ponadto w De consensu evangelistarum I 51: "Theatra, caveae turp1tudinum et publicae professionis"; "nequissimi scaenici"/De civitate II 4, 20/; "turpes et infames agunt sc. In scaena" 
szycie, przyblizymy augustyńska znajomość dramatu teatralnego, w drugiej zaś 1 trzeciej umieszczonej wastepnym zeszycie, scharakteryzujemy augustyńska młodzieńcza próbe twó rczości dramatycznej oraz jego teoretyczne uwagi na temat poszczególnych gatunków dramatu.

\section{AUGUSTYNSKA ZNAJOMOSC DRAMATU TEATRALNEGO}

1. Dramat teatralny w życiu św. Augustyna

Znajomość twórczości scenicznej zamdzięczał Augustyn przede wszystkim wiadomościom zdobytym wakole, jak równiez oglądaniu sztuk na scenie. Od dzieciństwa ciekawiły go przedstawienta sceniczne, dostępne dla starszych, urządzane w rodzinnej Tagaście $e^{3}$, posiadającej prawdopodobnie własny niewielki teatr*

negatywnego oddziaływania teatru 1 twórczości dramatycznej jest dla Augustyna az czterokrotnie wspominany przez niego młody sługa w "Eunuchu" Terencjusza, który z upodobaniem analizuje miłosną scenę Jowlsza/Eunuchus 583-591 = De civitate Dei II 7, 28 1 40; 12, 20; Confessiones I 16, 26; Epistola 91, 4/. Potępial on nie tylko przedstawienia mimów i pantomimór, lecz takze występujących w teatrach cytrzystów, którzy często bezwstydnie przedstawiali swoje teksty: "Talibus enim turpitudinibus cantionum animi humani illecti enervantur, et decidunt a virtute, fluentes in turpitudinem" /Sermo 9, 5/. F. G. Maier/Augustin und das antike Rom, Stuttgart 1955, 34/ bemerkt: "Kaum eine Erscheinung der romischen Kultur hat Augustin so radical verurteilt wie das Thea ter".

3 Confessiones I 10, 16, CSEL 33, 15, Kublak 14: "Moje nieposłuszeństwo wobec starszych nie polegało na wybieraniu rzeczy lepszych. Jego źródłem była pasja zabawy ... jak tez napawanie uszu przeróżnymi baśniami scenicznymi/falsis fabel11s) ... 0czy moje z coraz większa ciekawośctą otwierały się na takie widowiska, a były to widowiska dorosłych/ludos maiorum/".

4 H.Treidler/Tagaste,RE 2 Reihe IVA2, 2009/przyjmuje istnienie takiego teatru Tagaście, II. Kurfess natomiast/Heidnisches Milieu in Augustins Bekenntnissen, "Historische Blatter fetr die katholische Deutschland" 160/1917/, Bd. 2, 651/ nie dopuszcza takiej możliwości uważając, że przedstawienta sceniczne odbywały się wiej na Forum. 
Moźna przypuszczać, że nie wystawiono wim klasycznych dramatów, lecz przewaźnie mim, rzadziej pantomimę. Chociaz ogladanie widowisk teatralnych przez dzieci nie było zabronione, to jednak gdy z ich racji zaniedbywały sie one w nauce, były surowo karane ${ }^{5}$. Augustyn znajdywał mimo to sposoby, by na nie uczęszczać ${ }^{6}$. Z tekstami dramatów zetknąz się po raz pierwszy juz w szkole elementarnej podczas nauki czytania 1 pisania, przy której wykorzystywano m.in. fragmenty z komedii Terencjusza. Sam się skarżył, że obok słów pożytecznych poznał wówczas jako dziecko niemało gorszących historil o Jowiszu 1 wiele zbytecznych wyrażé, jak "złoty deszcz", "łono", "omamíc", sklepienie niebieskie", zaczerpnietych od tego komediopisarza ${ }^{7}$. Pełniejsza znajomość dramatu zdobył Aisustyn dopiero podczas swolch studiów gramatycznych w pobliskiej Madaurze, gdzie m.in.obowiązany by $¥$ poznać nie tylko podstawowych dramaturgów 8 , ale równiez mógł swobodnie uczęszczać do małego miejscowego

5 Confessiones I 10, 16, CSEL 33, 15, Kubiak 14: "... niemal wszyscy ludzie uważają za wskazane prowadzić tam swoje dzieci, potem zaś bez oporu pozwalają te dzieci bić, jeśli przez takie spektakle zaniedbały sie w nauce".

6 Confessiones I 19,30, CSEL 33, 27, Kubiak 22: "Nie podobałem sie nawet owym ludziom, gdyż ich niezliczona llość razy okłamywałen - pedagoga, nauczycieli, rodziców - aby uzyskać wolny czas na zabawy 1 gry ... na oglądanie głuplch widowisk, a wreszcie na nasladowanie tego, co widzlaIem na scenie/studio spectandi nugatoria et imitandi ludicra/".

7 Confessiones I 24-26, CSEL 33, 22-23: "didici in eis multa verba utilia ... legi et tonanter Jovem et adulterantem ... Ita ergo non cognosceremus verba haec, imbrem et oureum et gremium et fucum et templa coell et alia verba quae in eo loco/sc. in comoedis/scripta sunt, nisi Terentius induceret".

8 De civitate Dei II 8, CCL 47, 41: "comoediae scilicet et tragoediae ... quas etiam inter studia, quae honesta ac liberalia vocantur, gueri legere et discere coguntur a senibus". Por. H. I. Marrou, Historia w ychowania w starozytności, tł um. S. Loś, Warszawa 1969, 354, 389, 390. 
teatru 1 oglądac mystawiane tam mimy. Czy jednak spotkal sie wówczas z tekstami wielkich greckich tragików - Ajschylosa, Sofoklesa 1 Eurypidesa oraz komików Arystofanesa 1 Menandra, jest mało prawdopodobne, tym bardziej, ze zarówno wówczas, jak 1 późniejszycí studiach, odczuwał niechęć do greki, której nigdy dostatecznie nie poznat ${ }^{9}$; przekonanie to zdaje sie rónniez potwi erdzac brak jakiegokolwiek lch cytatu w całej jego późniejszej spuściźnie literackiej. Kaz tylko mspomina o roll Agamemnona " "tragedi1"10, ale trudno powiedzieć, czy w ogóle chodziło mu tu o greoki lub laciński dramat, czy tez o jakás drobna scene odgrywana przez pantomima. W Innym znó miejscu pisze o wysokiej społecznej pozycjt aktorów greckich Eschinesa 1 Arystodema, którzy mimo iz odgrywall tragedie, peinili później ważne funkcje państwowe, ale czyni to oparciu o "De republ1ca" Cycerona ${ }^{11}$.

Z łacińskich dramaturgów najlepiej poznał 1, jak później zobaczymy, najchętniej cytował objetego kanonem lektur szkolnych Terencjusza. Innych dramaturgow okresu republikańskiego, o których w jego czasach powoll zapominano, jak Enniusz, Plaut, Pakuwiusz, Newiusz, Cecyliusz, poznal tylko pobieznie 1 trudno przypuszczać, by $1 \mathrm{ch}$ osobiście czytał . Moźna natomiast przyjąć, ze mógł poznać z własnej lektury tragedie Seneki. Swoja

9 H. Funke, Euripides, JbAC 8/8 1965-1966, 276: "Dass August1n Euripides gekannt hat, ist nach seiner selbsbezeugten Abneigung gegen die griechische Sprache/Conf. I 20/ kaum zu erwarten". Por. A. Stepniewska, Czy lacińscy Ojcowio Kościoła znali tragediopisarzy greckich? "Vox Patrum" 6/1986/z. 11, 610-626; H. Jurgens, Pompa diabol1. Die 1ateinischen Kirchenvater und das antike theater, stuttgart 1972,34: "Augustin... kennt dagegen nur einige volkstelmliche Lieder aus griechischen Tragठdien"; G.Combes, Saint Augustin et la culture classigue, Par1s 1927,12:"Il ne sait rien, peut-on dire, du théatre grec".

10 De sermone Domini in monte II 5, PL 34, 1271: "Sunt enim hypocritae simulatores, tamquam pronuntiatiores personarum alienarum, sicut in theatricis fabulis. Non enim qui agit partes Agamamnonis in tragoedia verbi gratia, s1ve allcuius alterius ad historiam vel fabulam quae agitur pertinentis vere ipse est".

11 De civitate Det II 11, 1-8, CCL 47, 42-43: "... etiam scaonicos actores earundem fabularum non parvo civitatis honore dignos existimarunt, si quidem, quod in eo quoque de re publica libro commemoratur, et Aeschines Atheniensis, vir eloquentissimus, cum adulescens tragoedias actitavisset, rem publicain capessivit et Aristodemum, tragicum item actorem, maximus de rebus pacis ac belil legatum ad Philippum Athenienses saepe miserunt". 
znajomość starożytnego dramatu pogłębił Augustyn podczas retorycznych studiów posiadającej wspaniały teatr 1 obfitującej w różnorodne widowiska sceniczne Kartaginie ${ }^{12}$. Tutaj nie tylko juz musiał podczas ćwiczeń analizować 1 poznawać strukture klasycznych tragedil i komedii, ale mógł je w całośc1 lub we Pragmentach oglądac 1 słuchac w audytoriach lub w teatrze, w którym często, a nawet codziennie, odbywały się przedstawionid 13 .

Augustyn zdaje sie sugerować, że oglaqdaz tail jeszcze wystawiane "przyzwoitsze tragedie 1 komedie": "haec sunt scaentcorum tolerabiliora ludorum, comoediae videlicet et tragoediae, hoc est fabulae poetarum agendae in spectaculis" ${ }^{14}$. W oparciu o tę wypowiedź 1 spotykane nierzadko w jego twórczości terminy: "tragoedia", "traglcus", "comoedia", "comicus"15, dyskutuje

12 Enarrationes in Psalmum 103, 1, 13, CCL 40, 1486: "/Carthago/ ubi abundant spectacula".

13 o codziennych przedstawieniach Kartaginie por. De civitate De1 VII 26, 28, CCL 47, 208: "cotidie cantarentur et saltarentur in theatris"; Arnobius, Adversus nationes IV 36; Salvianis, De gubernatione VI 20; G. Charles-Picard, Le Carthage de saint Augustin, Paris 1965; G. G. Lepeyre A. Pellegrin, Carthage Latine et Chrétienne, Paris 1950.

14 De civitate Dei II 8, 17-18, CCL 47, 41.

15 Soliloquia II 18, 2, PI 32, 893: "aliud est falsum esse velle, allud verum esse non posse. Itaque ipsa opera hominum velut comoedias et tragoedias aut mimos et id genus alia possumus operibus pictorum fictorumque coniungere ... sed illa voluntate etiam verus tragoedus, eo videlicet quo Implebat, institutum"; De ordine II 39, CCL 29, 129: "Ad primum [sonum] pertinere tragoedos et comoedos vel choros culuscemodi atque omnes omnino qui voce propria canerent"; De sermone Domint in monte II 5, PL 34, 1271: "Sunt enim hypocritae simulatores, tamquam pronuntiatiores personarum alienarum, sicut in theatricis fabulis. Non enim qui agit partes Agamemnonis in tragoedia verbi gratia, sive allcuius alterius ad historlam vel fabulam quae agitur pertinentis, vere ipse est; sed simulat eum et hypocrita dicitur"; Sermo 198, 3, PL 38, 1026: "Etenim illa daemonia delectantur canticis vanitatis, delectantur nugatorio spectaculo et turpitudinibus varis theatrorum, insania circi, crudelitate amphitheatri, certaminibus animosis oorum qui pro pestilentibus hominibus lites et contentiones usque ad inimicitias suscipiunt, pro mimo, pro histione, pro pantomimo, pro auriga, pro venatore. Ista facientes quasi thura ponunt daemonils de cordibus suis"; De beata vita 2, PL 32, 960: "H1 sunt hoinines, quos cum vel lacrymablles tragoediae fortunarum suarum, vel inanium negotiorum anxiae difficultates 
się od dawna nad tym, czy rzeczywiście w 2, poł. IV w. wystawiano jeszcze w Afryce dramaty klasyczne. Tak na przykład Werner Welsmann uważa, ze komedie mogły być jeszcze wówczas gdzieniegdzie wystawiane, klasyczne natomiast tragedie juź nie, bo znikły od dawna ze scen łacińskiego Zachodu 1 milcza już o nich także źródła świeckie. Kiedy zaś Biskup Hippony wspomina "tragoediae ... agendae in spectaculis" lub uźywa westawieniu z mimami terminów "histrio", "cantans tragoediam", to ma na myśli przede wszystkim pantomimów luo tragediowych śpieliaków/tragicus cantor/, którzy ubrani w aktorskie szaty śpiewali pojedyncze wybrane fragmenty z greckich lub łacińskich tragedil, czy tez w oparciu o nie układali nowe ${ }^{16}$. Tego rodzaju "tragicy" znani byli w Rymie od początku cesarstwa, a role $1 \mathrm{ch}$ bez uwłaczania własnej godności grali nierzadko patrycjusze, a nawet cesarze, jak np. Neron ${ }^{17}$, wspominan1 takze przez autorów chrześcijańskich ${ }^{18}$. Ich występy określano ogólnie:

... in libros doctorum sapientissimorumque hominum truserint ...".

16 W. Weismann, K1rche und Schauspiele. Die Schauspiele im Urteil der lateinischen Kirchenvater unter besonderer Berflcksichtigung von Augustin, Warzburg 1972, 126-128 i 41.

17 Suetorius, Nero 21,3 : "Tragoedias quoque cantavit"; Tac1tus, Annales XV 65 i XVI 21; Philostratus, Vita Apoloni1 V 7 ; A. Lesky, Neroniana. Melanges H. Grégoire, Bruxelles 1949, 402-407; G. Wille, Musica Romana; Die Bedeutung der Musik Im Leben der Rømer, Ams terdam 1967, 1967, 338-350. o śpiewalcach tragicznych por. C. J. Grysar, ffber das Canticum und den Chor in der romischen Trag甘die, "Sitzungsberichte der Kaiserlichen Osterreichischen Akademie der Wissenschaften in Wien". Phil.-hist. Klasse 15/1855/370-394; G. Bo1ss1er, De la signification des mots saltare et cantare tragoediam, "Revue Archéologique" N. S. 4/1861/ II 339-343; L. Friedlander, Darstellungen aus der Sittengeschichte Roms, Leipzig 1922, II 123-124 i 177; G. J. Theochavidis, Beitrage zur Geschichte der byzantinischen Prophantheaters Im IV und V Jahrhundert, MUnchen 1940, 49-64.

18 Por. Firmicus Maternus, De errore profanarum religionum 6, 7; Ambrosius, De Elia et Leiunio 35147 ; Explanatio Psalmi 38, 1; Prudentius, Contra Symmachum II 647-648; Hieronymus, In Hiezechielel: X 33, 23-33. 
"tragoedias canere", to znaczy: "tragicum carmen canere. Ponadto nawet wówczas, gdy Augustyn mówi wyraźnie o "tragiku Roscjuszun19, to nie opiera się na własnych przemýsleniach, ale idzie za cycerońskimi uwagani o tym aktorze. Także jego wzmianki w "Wyznaniach" o oglądanych w teatrze budzących współczucie "luctuosa et tragica"20 1 o Medel, nie śriadczą wcale o oglądaniu granych jeszcze wówczas tragedil, jak to przyjmuja niektórzy badacze tych problemón ${ }^{21}$, ale raczej o oglaqdaniu pantomimy mającej za przedmiot wydarzenia opiewane $w$ tragediach, m.in. losy Medei.

Ukończenie studiów wartaginie nie przerwało kontaktu Augustyna $z$ dramatem scenicznym, nadal był zapanietałym bywalcem teatru. Co więcej, jako młody nauczyciel retoryki wzial udział 1 zwycięzył w kartagińskim agonie dramatycznym, układajz̨c, jak zobaczymy niżej, "carmen theatricum", za który prokonsul Windycjan ozdobil jego głowę "corona agonistica". Równieź później,podczas swego pobytu w Liediolanie posiadającym wspaniały teatr, bywał częstym jego widzem, chociaź gdy rozpoczą sie proces jego nawracania, czynil to coraz rzadziej 1 zahaniem, bo czuł w sobie wewnętrzne rozdarcie ${ }^{22}$. Dopiero radykalne wyrzeczenie się trzech pożąliwości i skoncentrowa-

19 Soliloquia II 10,18, PL $32,893$.

20 Confessiones III 2-4, CSEL 33, 44-47.

21 Por. A. MUller, Las Buhnenwesen in der Zeit von Konstantin bis Justinian, "Neue Jahrbtcher fur das klassischen Altertum" 23/1909/40; P. Schafer, Das Schuldbewustsein in den Confessiones des heiligen Augustinus, Würzburg 1930,48; G. Combes, Saint Augustin et la culture classique, Paris 1927, 42; H. Funke, Euripides, JbAC 8/9, 1965/1966, 276.

22 Por. Confessiones VIII 10, 23-24, CSEL 33, 189-190, Kubiak 146: "Ktoś się zastanawia, czy ma iść na zebranie manichejczyków, czy raczej do teatru ... ktoś z nas będzie sie wahat 1 miotal między dwoma sprzecznymi chęciami, czy ma iśc do teatru czy do naszego kościoła ... czy ma iść do cyrku czy do teatru, jeśli w jednym dniu odbywaja sie tu 1 tam przedstawi en $1 a^{\prime \prime}$. 
nie uwagi na problemie Boga, doprowadziło go do z trudem wypowiedzianegyo zdania: "Sane me iam theatra non rapiunt" "z pewnościa juź mnie nie pociagaja widowiska teatralne"23. Mimo jednak wymaganego przez chrześcijaństwo nyrzeczenta sie wszelkich widowisk, nie zrezygnowal nigdy z komedil Terencjusza, które prawdopodobnie nadal czytywał i szczególnie we wczesnych swoich pismach często cytował, ceniąc język 1 zyc1owa mądrość tego dramaturga ${ }^{24}$. Gdy później został kapłanem /391/ $i$ biskupein /396/ Pascynacja ta osłabła.

Będąc pasterzem IItppony, posiadającej odległy zaledwie o $400 \mathrm{~m}$. od jego bazyliki wspaniały mieszczący 6000 widzów teatr ${ }^{25}$, z którego często dochodziły oklaski i krzyki widzóm, prosi 1 nierzadko swoich rozkochanych widowiskach 1 uciekających na oglądanie "próżności 1 szalonych kłamstw" nawet - czasie nabozeństw wiernych: "Abstinete vos, quantum potestis, a nugatoribus spectaculis"26. Ubolewał, że do teatru uczęszczaja nawet duchowni ${ }^{27}$ oraz wielokrotnie wykazywał, że przez udział w tego rodzaju widowiskach scenicznych chrześcijanie sprzenie-

23 Confessiones X 35, 56, CSEL 33, 269, Kublak 208 .

24 Por. De beata vita 25, CCL 29, 78: "Verissima est enim 11la sententia: "nam tu quod vitare possis stultum admittere est, = Terentius, Eunuchus 761 .

25 Por. E. Marec, IIppone. Antique Hippo Regius, Alger 1950, 54-59.

26 Por. Sermo 9, 17, CCL 41, 141; Enarrationes in Psalmum 50, 1, $\mathrm{CCL}$ 38, 599: "Quam multos enim hodie fratres nostros cogitauus et plakgimus ire in vanitates et insanias mendaces, neglegere quo vocati sunt"; 30 II s. II 2 , CCL 38 , 203: "Quomodo autem non tribuletur iste/Dominus/ de hac multitudine, quando videt ipsos implere theatra et amphitheatra, qui paulo ante ecclesias impleverunt"; 30,12, CCL 39, 1400: "Nonne 1psi sunt qui theatra et amphitheatra implent per ludos et per alia spectacula, qui implent ecclesias per dies festos?"; 147, 7, CCL 40, 2144: "Et multum intent1 In illa spectacula, quae illis placent ... et aliquando nos quoque ibi sedimus et insanavimus; quam multos putamus 1 bi nunc sedere, futuros non solum christianos, sed etiam episcopos?".

27 Enarrationes in Psalmum 147, 8, CCL 40, 2145 : "Al Iquando dimisso theatro aut amphitheatro, cum coeperit ex illa cavea evomi turba perditorum ... vident plerumque ut fit transire servos Dei, cognoscunt ipso habitu ... et dicunt apud semetipsos et secum: o miseros istos, quid perdunt". 
wierzają się przyrzeczeniom chrzclelnym, a dla Innych sa zgorszeniem 28 . W oparciu o Cycerona podkreślat, że "nullo modo potuisse scriptiones et actiones recipi comoediarum, nisi mores recipientium consonarent" 29 . Ta negatywna biskupia postawa wobec widowisk teatralnych wyraziła sie równiez w zmniejszonym korzystaniu z tekstów twórczości scenicznej, nawet z ulubionych sztuk Terencjusza ${ }^{30}$. Nie do pomyślenia było u niego wykorzystywanie komedi1 kościelnym nauczaniu elementarnym, Jak to czynił współczesny mu Hieronim ${ }^{31}$. Dopiero po 413 r. złagodził nieco swój stosunek do sztuki scenicznej, co znalazło swój wyraz m.in. zwiększonej znów liczbie cytatów z Terencjusza, choć nie mógł się nigdy zdecydować na rewizje moralnych zarzutów przeciw niemu ${ }^{32}$

2. Dramat teatralny wisıach św. Augustyna

a. T r a g e d i a $\quad$ i k o m e d i a

Po tym krótkim scharakteryzowaniu stosunku św. Augustyna do twórczości scenicznej, warto się zastanowić, w jakim stopniu jej znajomość odzwierciedliła się wego pismach. Otóz nie znat on, jak juź wspominaliśmy, zadnych dramaturgów greckich z wasnej osobistej lektury oryginale 1 trudno sie doszukiwać u niego jakichkolwiek cytatów z lch dzieł. Z dramaturgów łacińskich znał jedynie i najczęściej cytował tylko Terencjusza.

28 Enarrationes in Psalmum 50, 1: 30 II $\mathrm{s}$. II 2; 99, 12; 147, 7; Sermo 51, 2; De catechisandis rudibus 11 i 48 .

29 Epistola 91, 4, CSEL 34, 430, 8-9.

$30 \mathrm{H}$. Hagendahl /Augustine and the Latin Classics, vol. II: Augustine's Attitude, G8teborg 1967, 378/ tak pisze o cytatach Terencjusza w tym czasie: "They consist mostly of short dicta, that had become proverbs, or phraseological reminiscences".

31 Por. Rufinus, Apologia contra Hieronymum II 11, CCL 20 , 92: "... etiam illud addatur, ubi cesset omne commentum, quod in monasterio positus in Bethleem .... Maronem suum comicosque ac lyricos et historicos auctores traditis sibi ad discendum Dei timorem puerulis exponebat".

32 Por. W. Weismann, dz.cyt., 132 1 165-166. 
Ten komediopisarz należący do rzymskiego kanonu autorów szkolnych, byl często cytowany równiez przez innych 0jców Kościoła. Stał się on szczególnie drog1 Augustynowi takze z Innych względów, bo pochodził z Kartaginy i lekturę jego komedil uważał nie tylko za szkolny, ale za swój zyciowy patriotyczny obowiazek. To żywe interesowanie się tym dramaturgiem znalazło swój wyraz w l1cznych czerpanych z nlego wypowiedziach, przytaczanych częściej od jakiegokolwiek Innego poety z wyjątkiem Wergiliusza. H. Hagendahl wymlenia 28 terencjusz orych fragmentów cytowanych w 40 miejscach pism św. Augustyna33. Pochodzą one z 5 komedil rzymskiego dramaturga, cytowanych zreszta najczęściej również

1 przez innych autorów wczesnochrześcijańskich, a mianowicle: "Andria" - $16 \mathrm{razy}^{34}$, "Eunuchus" - 10 razy", "Adelphoe" - 5 ra-

33 Zebrane w dziele: Augustine and the Latin Classics, I, G8teborg 1967, Testimonia 617-644 na ss. 254-264; cer A. P1ls, Augustinus quae hauserit ex Terentil comoediis, Wien 1921 /Mps/; H. Becker, Augustin. Studien zu seiner geistigen Entwiclung, Leipzig 1908, 75-77.

34 Andria w. 61 - De beata v1ta 32, 226, CCL 29, 83: "Unde illud praeclarum est et non inmerito diffamatur"; De doctrina christiana II 39, 58, CCL 32, 72; In Psalmum 118, Sermo 4, 1, PL 37, 1509: "1ilam memorabilem et nobilemque sententiam ... quam Graeci laudant in sapientibus suis et latini laudando consentiunt: ${ }^{6} \mathrm{Ne}$ quid nimis'1" w. $^{21}$ - Epistola 82, 31, CSEL $34 / 2$, 382, 14: "magis valet vulgare proverbium"; Confessiones $X$ 23, 34, CSEL 33, 253; w. 75 - De moribus Ecclesiae I 33, 70, PL 32, 1340; w。 126 - Eplstola 21, 2, CSEL 34/1, 50, 13; w. 189 - Epistola 258, 5, CSEL 57, 609, 7: "Menento quid mini dixeris profecturo comlcum quidem de Terentio recolens versum, sed tamen aptissimum et utilissimum"; w. 204 - De magistro 4, 9, CCL 29, 167: "cum seni domino apud Terentium servus rettulit"; w. 305-306 - De beata vita 25, 53, CCL 29, 79: "et 1lla eiusdem comici sententia non minus vera est"; De Trinitate XIII 7, 10, CCL $50 \mathrm{~A}, 395$ : "Hoc est enim, quod sapienter dixit Terentius"; De civitate Dei XIV 25, CCL 48, 448: "sicut ait Terentius"; w. 306-308 - De civitate Dei XIV 8, CCL 48, 424: "Porro apud Terentium flagttiosus adolescens"; w. 309 - Contra Julianum opus imperfectum IV 87, PL 45, 1387; w. 407-408 - Quaestiones in Heptateuchum IV 49 CSEL 28/2, 357, 11: "Positum est autem hoc verbum et in comoedia"; .730 De ordine I 7,20, CCL 29, 98 .

35 Eunuchus w. 59-61 - De c1vitate De1 XIX 5, CCL 48, 669, 12: "commemorat idem Terentius"; w. 257 - Contra Julianum II 7, 37, PL 44, 700; w. 583-591 - Confessiones I 16, 26, CSEL 33, 23, 12: "nisi Terentius induceret nequam adulescentem proponentem sibi Iovem"; tamże, CSEL 33, 23; Epistola 91, 4, CSEL 34/2, 249, 21: "Et re vera Terentianus ille adulescens"; De civitate Dei II 7, CCL 47, 40, 29: "Hinc apud Terentium flagitiosus 
$\mathrm{zy}^{36}$, "Phormio" - 5 razy", "Hautontimorumenos" - $4 \mathrm{razy}^{38}$. Wykaz Hagendahla uzupełnia w pewnym stopniu Heiko Jargens ${ }^{39}$, odkrywając kilka terencjańskich wypowiedzl głównie w augustyńskich regułach, a mianowicie: 5 nowych Pragmentów z "Andrif 2 z "Eunucha"41 i 1 z "Formiona"42. Znaczące jest równiez roz-

adulescens spectat tabulam"; De civitate Dei II 12, CCL 47, 44, 20: "et dignum fuit, ut Terentius vester flagitio Iovis"; w. 761 - De beata vita 25, 44, CCL 29, 78: "Verissima est enim 11la sententia"; w. 1024 - De ordine I 3, 9, 72, CCL 29, 93: "non dictum est commodius apud Terentium quam nunc dici a me"; w. 1029 - Contra Julianum III 5, 11, PL 44, 708.

36 Adelphoe w. 57-58 - Epistola 185, 21, CSEL 57, 19, 11: "Proponunt nobis quidam sententiam cuiusdam saecularts auctoris qui dixit"; w. 69-75 - Epistola 185, 21, CSEL 57, 19, 18: "Nam ut de ipso auctore/sc. Terentio/ istis respondeatur"; w. 769 - Epistola 26, 3, CSEL 34/1, 85, 9: "Hic tu fortasse Terentiani servi mihi responsum dederis"; w. 823825 - Epistola 138, 4, CSEL 44, 129, 11; w. 867-868 - De c1vitate De1 XIX 5, 8-9, CCL 48, 669: "Adudiant apud comicos suos hominem cum sensu atque consensu omnium hominum dicere".

37 Phormio w. 318 - Epistola 155, 5, CSEL 44, 435, 12; w. 419 De ordine II 7, 21, CCL 29, 118; w. 541 - Epistola 40, 3, CSEL 34/2/,73, 2; w. 780 - Confessiones VI 11, 18, CSEL 33, 132; Contra Julianum opus imperfectum IV 34 , PL 45 , 1355 .

38 Hautont1morumenos w. 75-77 - Epistola 155, 14, CSEL 44, 444, 14: "Hinc et 1110 comicus"; Contra Jullanum IV 16, 83, PL 44, 781; w.719 - Contra Petilianum III 21, 25, CSEL 52, 181,16 ; tanże, III 22,16, CSEL $52,182,15$.

39 H. Jutargens, Pompa diaboli, dz,cyt., 112-145.

40 Andria $\mathrm{w} \cdot 67-68$ - Confessiones XII 30, 41, CSEL 33, 342; w. 69 - Regulae, GL V 519, 31-33: "/quamquam lectum sit abhinc apud Terentium/ Interea mulier quaedam abhinc triennium"; w. 74-75 - Regulae, GL V 517, 8-9: "Terentius/ vitam parce ac duriter agebat/pro dure/"; w. 211 - Regulae, GL V 509, 29-31: "unde et Terentius dixit"; w. 426 - Regulae, GL V 509, 33-35: "quae proverbia dicuntur, ut Terentius dixit".

41 Eunuchus w. 315 - Regulae, GL V 497, 41: "/Terentius de virgine/ pugilem esse aiunt"; w. 331-332 - Contra academicos III 16, 35, $\operatorname{CCL} 29,56$ : "liquet deierare/... nescire me/ prorsus".

42 Phormio w. 780-781 - Confessiones VI 11, 18, CSEL 33, 132, 18: "/iam tricenariam aetatem gerebam/ in eodem luto haesitans". 
mieszczenie tych cytatów: najwięcej ich jest, jak moźna było się spodziewać, w dialogach 1 w listach, najczęściej przytaczane przed przyjęciem kapłaństwa 1 pod sam konlec zycia. Jeśli chodzi o dzleła teologiczne, to w pismach z lat 387-413 11czacych w "Patrologii" Migne'a blisko 3200 kolumn, dostrzegamy niemal calkowite zerwanie z ulubionym komediopisarzem; znajduje sie w nich zaledwie 5 cytatów, sprowadzonych do krótkich sentencji i frazeologicznych reminiscencji ${ }^{43}$. Po tym okresie wzrasta znów l1czba terencjańskich cytatów, z tym ze sa one przytaczane $z$ racjl ascetycznych, jak np. kilkakrotnie wspominana scena z "Andrii"/w. 305-308/ o ocentajacym postepowanie Jowisza niewolniku. Przy cytowaniu nie wymienil jednak nigdy tytułu cytowanej komedil, ani nie objaśniał bliżej i nie oceniał jej autora, jak to niekiedy czyniz podczas przytaczania innych pisarzy 44 , ale albo bezimiennie włączał jego wiersz w swój tekst, albo teź krótko wskazywał na jego pochodzenie formula: "sicut ait/dixit, commemorat, inducit/ Terentius"45. "ut apud Terentium"46, "ut Terentianus 11le adulescens/servus/ dixit"47, "ut comicus de Terentio versus" 48 "ut 1110 comicus" 49 , "verissima est ista comici sententia"50, "ut positum in comoed1a"51, lub ogólniej: "ut vulgare proverbium", "ut 1lla memorabilis et nobilis sententia", "ut 1llud praeclarum"52, jako te

43 Por. H. Hagendahl, dz.cyt. II 378 /por. wyzej n. $30 /$.

44 Por. Homer /Confessiones I 16/, Pithagoras/De consensu evangelistarum I 12; De ordine II 53/, Socrates/De consensu evangelistarum I 12/, Plato/De c1vitate Del VIII 4; XVIII 37; De consensu evangelistarum I 12/, Plotinus/Contra academicos I 1; II 5/, Sallustius/De beata vita 31/, Varro/De civitate Dei XIX 22/, Cicero/Confessiones IV 7 .

45 De civitate DeI XIV 25, 15; XIX 5, 12; II 12, 20, CCL 48 , 448; 669; CCL 47, 44; De Trinitate XIII 7, 10, 57, CCL 50 A, 395; Confessiones I 16, 26, CSEL 33, 23, 13-21.

46 De magistro 4, 9, 88, CCL 29, 167; De civitate Dei II, 7, 28 $1 \mathrm{XIV} 8,65, \mathrm{CCL} 47,401 \mathrm{CCL} 48,424$; De ordine I 3, 9, 72 , CCL 29, 93 .

47 Epistola 91, 4, CSEL $34 / 2,429,21 ; 26,3, \operatorname{CSEL} 34 / 1,85,9$. 48 Epistola 258, 5, CSEL 57, 609, 7 .

49 Epistola 155, 14, CSLL 44, 444, 14; De civitate De1 XIX 5, CCL 48, 669.

50 De beata vita 25, 44-45, CCL $29,78$.

51 Quaestiones de Heptateucho IV 49, CSEL $28 / 2,357,11$.

52 Epistola 82, 31, CSEL 34/2, 382, 14; In Psalmum 118 Sermo 4, 1, PL 37, 1509; De beata vita 32; 226, CCL 29, 83; 
wiele terencjuszowskich wierszy stało sie z czasem przysłowiami $^{53}$ I Augustyn mógł je czerpać także z tego źródła nie znając nawet 1ch pochodzenia. Formuly te świadcza niewatpliwie - jego dużym uznaniu dla terencjańskiej sztuki tworzenia maksym 1 ich życiowej wartości ${ }^{54}$. Augustynow1 znane są równiez imiona niektórych postaci występujących w komediach Terencjusza, jak Chremes 1 Parmeno występujący w "Eunuchu"55 oraz Glycerium ${ }^{56}$, które w Jakimś stopniu suponuja także znajomość tych dramatów.

Innych lacińskich dramaturgów okresu republikańsklego Biskup Hippony zna tylko z imienia, a jeżeli któregoś z nich cytował, to czynił to zawsze bezimiennie z drugiej ręki. Nie był jednak w tyin odosobniony, bo $w$ IV 1 V w. ogólnie juz o nich zapomniano $i$ nawet na Zachodzie już bardzo rzadko na nich sie powoływano. Tak więc raz wspomina razem Newiusza, Cecyliusza 1 Plauta w prytoczonym fragmencie z "De republica" Cycerona 1 raz cytuje tego ostatniego komediopisarza przytoczonym Pragmencie z "De gente populi Romani" Warrona 58 . Imiona tych dramaturgów sa jednak dla Augustyna pustymi terminami znanyral tylko z Cycerona 1 Warrona. Bezimiennie ponadto cytuje

Epistola 185, 21, CSEL 57, 19, 11.

53 Por. A. Otto, Die Sprichworter und sprichwortlichen lledensarten der Romer, Leipzig 1890, 368, 225, 16 .

54 Epistola 258, 5, CSEL 57, 609, 6-8: "comlcum quidem de Terentio versum, sed tamen aptissimum et utilissimum"; Epistola 155, 14, CSEL 44, 444, 12-15: "Hinc et 11le comlcus, sicut luculentis ingenils non depit resplendentia veritatis".

55 Ep1stola 7, 2, 4, CSEL 34, 15, 19-20.

56 Por. Regulae, GL V 498, 2.

57 De civitate De1 II $9,15-16$, CCL $47,41=$ Cicero, De republica IV 10, 11-12/Prg./: "quam si Plautus, Inquit, noster voluisset aut Naevius Publio et Gn. Scipioni aut Caecilius Marco Catoni maledicere".

58 De civitate De1 XXI 8, 24, CCL 48, 771 = De gente populi Romani /Amphitrio 275\%: "stella Veneris nobilissima, quam Plautus Vesperug1nem -... appellat"; por. Hagendahl, dz.cyt., s. 219, test. 506 . 
raz fragment wiersza $z$ "Ifigenil" knniusza" 59 oraz trzykrotnie wsponina/raz cytuje/ pewne miejsce z dramatycznej twórczości Pakuwiusza o "latającej Medei"6C. Pakuwiański motyw dziwnego latającego potwora musiał wywrzeć na młodego Augustyna duże wrazenie, skoro go az trzykrotnie wspomina i prawdopodobnie czyni, jak zobaczymy nizej, przedmiotem próby swej dramatycznej twórczości. Nie jest równiez wykluczone, że Biskup Hippony mógł osobiście czytać istniejące jeszcze fragmenty dramatycznej twórczości Pakuwiusza lub znać ten motyw z przekazywanej ustnie tradycji, choć Hagendahl uważa, że zna go on na pewno z Cycerona 61 .

Z dramaturg6w natomiast okresu cesarskiego Augustyn cytuje tylko bezimiennie dwukrotnie Seneke z formuła "quidam tragicus att"62 i raz mniej znanego tragediopisarza Pomponiusza Sekundusa bez jakiegokolwiek blizszego określenia ${ }^{63}$ przy omawianiu metrów wierszowych. Ta znikoma liość cytatów z twór-

59 Confessiones X 16, 25, CSEL 33, 244: "Neque enim nunc: scrutamur plagas caeli aut siderum intervalla demetimur" /TRF Ribbeck s. 47/. Jego źródłem jest prawdopodobnie Cyceron, De republica I 30, Hagendahl, test. 377, s. 172,

60 Pacuvius, tr. 1nc. XXXVI /397/R, /TRF 150, wg Weismanna/, Cicero, De republica III, 14 : Augustinus, Soliloquia II 15, 29, PL 32, 898: "Non enim cum dicitur: iunctis al1t1bus anguibus Medeam volasse"; Epistola 7, 2, 4, CSEL 34/1, 15, 17: "ego Medeae cum suis sanguibus alitibus iunct1s lungo"; Confessiones III 6, 11, CSEL 33, 53, 2-4: "Nam versum et carnem etiam ad veram pulmenta transfero; volantem autem Medeam etsi cantabam, non asserebam, etsi cantari audiebain, non credebam"; Hagendahl, test. 492, na ss. 214215.

61 Hagendahl, dz.cyt. s. 377: "There can be no doubt that the got the line from Cicero who quotes it anonymously for the same purpose" /Cicero, De inventione I 27: "Fabula est, in qua nec verae nec veri similes res continentur, culusmodi est: "Angues ingentes alites luncti fugo"/.

62 Seneca, Phaedra 200-201 = Contra Faustum XX 9, CSEL 25/1, 545, 8; Troades 291-292: u Augustyna Sermones Frangipani $8,5 / \mathrm{MA}$ I 231, 10/, Hagendah1, test. 585-586, s. 245.

63 Pomponius Secundus, Frg. 8-11/TRF 268/ = De musica IV 31, PL 32, 1144, Hagendah1, test. 525, s. 223-224. 
czości najwybitniejszego rzymskiego tragediopisarza okresu cesarstwa świadczy niewątpliwie, ze jego dramaty nie wywarły na przyszłym biskupie Hippony zbyt wielkiego wrazenia, podobnie zreszta, jak 1 na Innych łacińskich Ojcach Koscioła, jakkolwiek moźna przypuszczać, ze wspomniane wyzej cytaty mógł zaczerpnác z osobistej lektury jego sztuk ${ }^{64}$. Postać bowiem 1 pisma tego filozofa stolka, który jak sam zauwaza, "cieszyz się rozgłosem za czasów apostolskich", ale jego źycie odbiegało od głoszonych zasad ${ }^{65}$ były mu, jak się ogólnie przyjmuje, dobrze znane. IF "De civitate Dei" przytoczyz imiennie 1 z wymienieniem tytułu aż 8 cytatów z jego traktatu "Contra superstitiones", przeciw przesadom, mitologii i rzymskiej teologil państwowej ${ }^{66}$ chociaz stosunek do niego miał zawsze raczej enigmatyczny. Drugiego zaś współczesnego Senece tragediopisarza Pomponiusza Sekundusa Augustyn zewnościa nie czytal, przytoczony natomiast jego fragment maczerpnąz z pisma zyjacego pod koniec III w. Terencjanusa Maura ${ }^{67}$.

\section{b. P a n t o m 1 m a}

O wiele mniej Informacji przekazal nam Augustyn o pozostałych gatunkach dramatycznych - pantomimie 1 mimie, mimo iz przed swym nawrócenien oglądał je na pewno z upodobaniem wielo-

64 Por. W. Weismann, dz,cyt. 125.

65 De c1vitate De1 VI 10, 1, CCL 47, 181, Kornatorsk1 I 325; Epistola 153, 14, CSEL 44, 412: "Seneca qui temporibus apostolorum fuit, culus etiam quaedam ad Paulum apostolum leguntur epistolue".

66 De civitate Dei VI 10-11 I V 8 CCL $47,181-183,135-136$. Hagendahl test. 587-594, s. 245-249; J. E, d'Angers, Refutation et utilisation augustiniennes de Seneque et du stolcisme, "Revue des Etudes Augustiniennes" 2/1956/471-503; P. de Labriolle, Saint Augustin et Sénéque, "Revue de philo$\log 1 \mathrm{e} "$ 54/1928/47-49; Hagendah1 s • 677-680.

67 Hagendahl s. 475: "They are no doubt taken over from Terentianus /v. 2138-2141/, who attributes them to a tragic chorus of Pomponius Secundus". 
krotnie na scenie. Pantomima, pochodna tragedil, cieszyła sie aż do końca cesarstwa dużym powodzeniem szczególnie wśród inteligencji. W jej strukturze można było wyróżnić: występującego na koturnach 1 ubranego w drogocenne jedwabne szaty oraz tragediowa raskę o zamknietych ustach przeważnie męskiego jednego aktora-tancerza, który jrzy pomocy ustalonych gestów przemawlat do publiczności rękami i ruchami ciała odgrywając po kolei /dzięki zaianie mašek/ róźne role, w tym takźe kobiece oraz stojacy na scenie 1 śpiewajazcy przy wtórze muzyici instrumentalnej/symphoniaci: cytra, flet, organy $i$ do wybijania rytmu tzw. scabellum/ fragment jakiejś tragedii lub specjalnie ułożone pod jej wpływen najczęsciej po grecku o tematyce mitologicznej libretto/canticum/68. W zwiazku z tego rodzaju tematykaz akcję aktora pantomimy określano często na Zachodzie, jak juz wspominaliśmy, wyrażeniew "saltare tragoedian". Aktora zaś tegoź przedstawionia nazywano na Zachodzie przewaznie "histrio", lub rzadziej wprost "pantomimus". Augustynowi znane są te obydwa określenia z tyu, ze termin "histrio" odnosiz przeważnie do aktorów występujących ra scenie w ogóle 69 , któ-

68 Por. Lukianos, Le saltatione; Libanios, Pro saltatione /Orat1o 64/; Theocharidis, dz.eyt. 20-48; V. Rotolo, Il pantomimo, Yale rmo 1957 ; E. Wetst, Pantomimus, REXVIII/2, 833-869; H. Bier, De saltatione pantomimorum, Bonn 1920; 0. We1nre1ch, Epigram und Pantomimus, Heidelberg 1948; o. Pasquato, Gli spettacoli In S. Giovanni Crisostomo, Roma 1976, 137-160.

69 Por. De civitate Dei I 32, 24, $\mathrm{CCL} 47,32$ : "in tileatris cotidie certatim pro histrionibus insanirent"; II 11, 13 , $\mathrm{CCL}$ 47, 43: "vitan civium lacerandam linguis poetaruñ et histrionum subtrahere ausi sunt"; IV 26, 35, CCL 47, 120: "In illis ludis corruptorem pudicitiae Jovem turpissimi histriones cantabant agebant placebant"; Sermo 90, 5, PL 38, 562: "qui simul malepicia, qui simul histriones amant"; Sermo 332, 1, PL 38, 1461: "diligunt invicem qui histriones simul spectant ... aneretis invicem, qui simul diligeretis histrionew"; Sermo 198, 3, PL 38, 1026: "litis et contentiones usque ad inimicitias suscipiunt, pro mino, pro histrione, pro pantomimo, pro auriga, pro venatore"; Serio Denis 14, 3, NA I 68: "optiue fecit antiqua disciplina Romana, quae omne genus histrionum in infami loco deputavit"; Sermones lirangipane 5, 5, MA I 216: "Nonne vides homines res suas effundentes histrionibus": De musica I 2, 2, rL 32, $1084 \Lambda$ : "Non enim tale aliquid hic discendum est, qualo quilibet cantores histrionesque noverunt"; Le lausica I 6, 11-12, PL 32, 1089-1090: "inter nos posse intstriones sine ista scientia/musicae/ satis- 
rych także nazywał "scaenici" /actores/70, a rzadziej do aktorów pantomimy ${ }^{71}$; w tym drugim wypadku teruin ten bardzo często wzmacnial przydawką: "saltator", "saltans"72. Terininu technicznego natomiast "pantomimus" uży kilka razy bez blizszego wyjaśnienia, juź to zestawiając go z mimem lub innymi akto$\operatorname{rami}^{73}$, już to ubolewając, że nawet chrześcijanom podoba się on

facere voluptati aurium popularium ... ita etiafi nullo modo esse posse histriones musicae studiosos peritosque constiterit ... hoccine igitur pretio cantus suos venderent histriones, si inusicam scirent ... vel ostenseris quemlibet histrionum ... concedam posse quemquam et musicae habere scientiam et esse histrionem ... perprobabile est neminem esse histrionum qui non sibi professionts finem in peccunia ... Patere necesse est, aut music nescire histriones ... sed honorandi aliquando histriones possint videri"; Enarrationes in PS $39,8,31$ i 9, 29, CCL 38, 4311432 : "Quis est iste amator et laudator illius venatoris, illius histrionis ... nunc specta histrionem/linoskoczka/"; Enarrationes in Ps 53, 10, 23, CCL 39, 653: "laudatur ab studiosis theatricarum nugarum vel auriga vel venator vel quilibet histrio"; Enarrationes in Ps 102, 13, 29, CCL 40, 1463: qui donat histrionibus, qui donat aurigis, qui donat meretricibus"; De Plde et operibus 18,33 , PL 40 , 219: "non admittuntur ad baptismum ... quando meretrices et histriones et quilibet alii publicae professores"; De consensu evangelistarum I 33, 51, CSEL 43, 56, 12: "Nonne Cicero eorum cum Roscium quendam laudaret histrionem".

70 Por. De civitate Dei II 4, 20, CCL 37, 37: "talia per publicum cantabantur a nequissimis scaenicis"; II 11, 1 i $20, \operatorname{CCL} 47,42,143$ : "etiam scaenicos actores earundem fabularum non parvo civitatis honore dignos existimarunt ... et scaenicos probrosos haberent".

71 Por. De civitate Dei II 6, 13, CCL 47, 39: "ludi non agerentur obscenis vocibus et lotibus histrionum"; II 29, 41, CCL 47, 64: "Bene, quod tua sponte histrionibus et scaenicis societateli civitatis patere noluisti".

72 Por. De magistro 3, 5, 34-38, CCL 29, 163: "nam et histriones totas in theatris pabulas sine verbis saltando plerumque aperiunt et exponunt ... ne ipse quiden saltator histrio tibi sine verbis quid significet posset ostendere"; De doctrina cinristiana $1125,38,7, \mathrm{CCL} 32,60$ : "Illa enim signa, quae saltando faciunt histriones"; Épistola 91, 5, CSEL 34, 430: "rideantur in theatris ... cum haec histriones agunt et saltant".

73 Por. Serino 198, 3, PL 38, 1026: "lites et contentiones usque ad inimicitias susciplunt pro rillo, pro histrione, pro panto- 
wiecej niż sam Bóg ${ }^{74}$. Nie mówi jednak nic bliżej na temat struktury tego gatunku dramatycznego. Nie wymienia aktorów an1 twórców układanych kantyków. Ówczesny afrykański biskup Quodvultdeus mspomina o kuszącym, ale burzącym zdrowy rozsądek śpiewie pantomimicznego chóru" , Augustyn zaś o "demońskich kapelmistrzach" /symphoniaci daemoniorum/ posługujących się charakterystycznymi dla pantomimy instrumentami muzycznymi: scabellum, cymbały, flety 1 organy ${ }^{76}$. Przestrzega teź swoich wiernych przed muzyka teatralną, aby za jej pośrednictwem nie wracać do "teatralnych bredni"/theatricas nugas/77. Trudno jest nieraz rozróżnić, czy chodzi o muzyke pantomimów, mimów, czy też teatralne konkursy muzyczne.

Dialog, nieodłaczny składnik kazdego dramatu, wantomimie prowadzony jest poprzez pewne umowne znaki $i$ gesty, które aktor wykonuje nie tylko rekami, ale całym ciałem, a nawet oczami. To mówienie rękari poprzez ustalone gesty/gestus

mimo, pro auriga"; Sermo Denis 17, 7, MA I 87: "Tu specta mimum, specta pantomimum": Enarrationes in Ps 30 II $s .3,11$, 10, CCL 38, 221: "Cui dico, ut diligat Dominun, qui adhuc diligit mimum, qui adhuc diligit pantomimum"; Bnarrationes in Ps 103, s. 1, 13, 9, CCL 40, 1486: "Videte autem ne putetis nominata alegoria, pantomimi aliquid me dixisti".

74 Enarrationes in PS 32 II S. 1, 1, 20, CCL 38, 247: "111is facilius placet pantomimus quam Deus" :

75 Quodvultdeus, De symbolo I 2, 16, CCL 60, 38: "Chorus 1111c et cantio pantomimi lilicit auditum, sed expugnat sanum affectum".

76 Por. De musica III 1, PL 32, 1115: "velut cum symphoniaci scabelia et cymbala pedibus feriunt, certis quidem numeris et his qui sibi cum aurium voluptate iunguntur, sed tanen tenore perpetuo, ita ut si tibias non audias"; Contra Gaudentium I 51, PL 43, 737: "aut stabunt adversus vos syluphoniaci daemoniorum, quorum tibias et scabella fregistis, quod et nos fecimus"; Enarratio in Ps 69, 2, CCL 39, 931: "adhuc tamen inter organa et symphoniacos gemimus"; Sermones Caillau II 19, 7, MA I 270: "Quanta luxuria redundavit propter theatra et organa et tibias et pantomimos".

77 Por. De doctrina christiana II 28, CCL 32, 53: "nos tainen non propter superstitionem profanorum debemus musicam fugere ... nec ad illorum theatricas nugas converti, si aliquid de citharis et de organis ...". De musica I 6, 1112 i VI 7, PL 32, 1089-1090 i 1166; Contra Faustum Manichaeum XXII 94, PL 42, 463; Enarrationes in Ps 32, II s. 1, 5, CCL 38,250 。 
sine voce/, któryml można było wyrażać nawet abstrakcyjne pojęcla tilozoficzne, dźwięki, zapachy i przyimki ${ }^{78}$, od dawna budziłq podziw nie tylko u autorów pogańskich ${ }^{79}$, ale 1 chrześcijańskich ${ }^{80}$. Równieź Augustyn patrzył $z$ podziwem na gestykulacje pantomimów. Podkreślał, że aktorzy c1 przy pomocy pewnych znaków, wykonywanych członkami ciała, jakby przez niesłyszalne słowa, potrafia przekazać przygotowanym do lego ludziom głębokie tajniki rzeczy, nawet takie, których głosem wyrazić nie można ${ }^{81}$. W tańcu pantomima kazdy ruch coś wyraza, oznacza lub symbolizuje, poniewaz jest skutkiem dzialania rozumu, chocby zewnetrznio sprawlał przyjemność tylko zmysłom 8 ? Zaznacza jednak, ze "choclaz aktorzy teatrze odtwarzaja bez słów całe sztuki przy po-

78 Por. Libanios, Oratio 64, 119/Pro saltatione/; Athenalos, Delpnosofistai I $20 \mathrm{CD}$; Augustinus, De magistro 3, $6 \mathrm{CCL} 29$, $163 /$ zob. nota $81 /$.

79 Por, Joneca, Epistola 121, 6: "Mirari solemus saltandi peritos quod in omnem significationem rerum et adfectum parata 11lorum est manus et verborum velocitatem gestus adsequitur".

80 Por. Tertul11anus, De 1dololatria 5, 2, CCL 2, $1105:$ "credo.. - nistriones vero non manibus solis, sed totis membris victum elaborare"; Novat1anus, De spectacul1s 6, 6, CCL 4, 175: "homo Iractus omnibus membris et vir ultra muliebrem moll1tiem dissolutus, cui ars sit verba manibus expedire"; o sztuce mówienia rekami u autorów starozytnych zob. 0 . Weinreich, Epigram und Pantomimus, dz. cyt.,140-145/ Die "Kunst der Hunde" In Pantomimus/.

81 De doctrina christiana II 4, 6-8, CCL 32, 34:"Et histriones omnium membrorum motibus dant signa quaedam scientibus, et cum oculis oorum quasi fabulantur... et sunt haoc omnia quasi quaedam verba invisibilia"; De magistro 7, 19, 31-34, CCL 29, 178: "Nesc1o quomodo ad surdos et histriones devenimus, qui non sola, quae videri possunt, sed multa praeterea ac prope omnia quae loquimur gestu sine voce significant; oosdem tamen gestus signa esse comperimus".

82 De ordine II 11, 34, CCL 29, 126: "Sed histrione saltante cum bene spectantijus gestus ilii omnes signa sint rerum, quamvis membrorum numerosus quidam motus oculos eadem 111 a dimensione delectet, dicitur tamen rationabilis illa saltatio, quod bene aliquid significet et ostendat excepta sensuum voluptate". 
mocy ruch6́w wykonywanych w tańcu" 83 , to jednak trzeba wymagać, by $w$ tych znakach 1 gestach przyjetych umownio "zachodz1ło Jakieś podobieństwo znaczentowe, a jeśli to możliwo, by same zna$k 1$ nosiły podobieństwo do rzeczy oznaczanych"84. Umowne znaczenie tych znaków sprawia, ze gdy ktoś nie znający ioh treści wejdzie do teatru, by oglądac aktora pantomimy, to nie zrozumie jego gestów. W zwiazku z tym faktem Biskup Hippony przekazuje nam nawet pewien szczegó z historil pantomimy, informujac, ze w nleodległych mu czasach, o czym pamietaja jeszcze ludzie starsi, wystep aktora pantomimy w Kartaginie poprzedzał specjalny nerold/praeco/ , który zapowiadał tytuł 1 bleg akcji przedstawianej sztuki oraz niektóre jego trudniejsze gesty, bo inaczej nie byłby zrozumlazy dla nie przygotowanych widzów 85 .

$Z$ pewnych wreszcle wyporiedzi 1 aluzj1 św. Augustyna można odczytać niektóre przynajmniej tematy przedstawianej wowczas pantomimy. Była to głównie tematyka mitologiczna, prezentowana wcześniej tragedil. Gdy ta ostatnia zamarła, Punkcje propagowania

33 De magistro 3,5-6, CCL 29,162-163, tłum. J.Modrzejewski, DF III 24: "Quod cum fit, non utique sola visibilia sine verbis ostenduntur, sed et soni et sapores et cetera hulusmodi; nam et histriones totas in theatris fabulas sine verbis sal tando plerumque aperiunt et exponunt. Nih1l habeo, quod contradicam, nisi quod illud "ex" non modo ego, sed ne ipse quidem saltator histrio tibi sine verbis quid significet posset ostendere. Verum fortasse dicis; sed fingamus oum posso, non ut arbitror dubitas, quisquis ille motus corporis fuerit, quo mihi rem, quae hoc verbo significatur, demonstrare conabitur, non ipsam rem futuram esse, sed signum. Quare hic quoque, non quidem verbo verbum, sed tamen signo signum nihilo minus indicab1t, ut et hoc monosyllabum "ex" et ille gestus unam rem quandam significent, quam mihi ego vellem non significando monstrari".

84 De doctrina christiana II 25, 38, CCL 34, 60, PSP 22, 58: "Appetunt tamen omnes quandaw similitudinem in significando, ut ipsa signa, quantum possunt, rebus quae significantur, similia sint".

85 Tamze, "Illa enim signa, quae saltando faciunt histriones, si natura, non instituto sed consensione hominum valerent, non primis temporibus saltante pantomimo prasco promunciaret populo Carthaginis, quid saltator vellet intellegi. Quod adhuc multi meminerunt senes, quorum relatu haec solemus audire. Quod ldeo credendum est, quia nunc quoque si quis theatruin talium nugarum imperitus intraverit, nisi ei dicatur ab astero, quid 1111 motus significent, Prustra totus intentus est". 
mitologil przejeła, jak stwierdza Libanios ${ }^{86}$, pantomima. Autorzy wczesnochrześcijańscy pietnując współczesne sobie przedstawienta teatralne 1 oskarzajac je m.in. o przypominanie 1 nauczanie mitologi1, mieli na myśli głómnie pantomime, która lubowała się gzczególnie odtrarzaniu erotycznych historil 1 niemoralnych scen $z$ zycla bogow, a zwłaszcza Jowisza 87 . Wiele z tych historil było, otwlerdza Augustyn, za jego czasó codziennie w pantomimio przedstawlanych 88 , a szczególnym powodzentem cleszyły sie prezentowane $w$ niej milosne perypetie Jow1sza 89 Takze owe wspominane w "Wyznaniach" luctuosa et tragica" oraz "calamitates 111e hominum"90,

86 Pro saltatione 112, tłum.L.Małunow1czówna/ Libanios, Wybór mów, Wrocław 1953/,368: "Jak długo więc twórczośc sceniczna była wozkwlele, przemawlali ze sceny nauczyciele dostepni dla mas. Gdy zamilkt ich gł08... wprowadzono na miejsce dramatu taniec pantomimiczny, jako perne pouczenie ludu o dawnych dziejach. I teraz złotnik całkiem nieźle będzie rozprawial zimś,kto wyszedz ze szkó, o rodzie Priama 1 Lajosa".

87 Por. Minucius Felix, Octavius 37,12:"histrio... deos vestros Induendo stupra suspiria odia dedecorat"; Cyprianus, Ad Donatum 8, 163-171, CCL 3A, 8: "Exprimunt/histriones/.10. Jovem 11lum suum non magls regno quam vitils principem, in terrenos amores cum ipsis suis fulminibus ardentem, nunc in plumas oloris albescere/Leda/, nunc aureo imbre defiuere/Danae/, nunc in puerorum pubescentium raptus ministris avibus prosilire /Ganimedes/: Tertullianus, Apologeticus 15,2; Ad nationes I 10,45; Novatianus, De spectacul1s 6,4; Arnobius, Adversus nationes IV 35, VI 26, VII 331 35; Firmicus Maternus, De errare profanarum religionum 12,9 .

88. De c1vitate De1 IV 10,72-76, ICL 47,107-108: "Rursus, inquiunt, ad fabulas redis ... qui haec in theatris libentissime speotant crimina deorum suorum? ... haec ipsa theatrica crimina deorum in honorem instituta sunt eorundem deorum"; In Joannem tractatus $97,3,11-15$, CCL 36,574 : "Utinam tales quales in theatris sive cantantur, sive saltantur, sive mimica scurrilitate ridentur, ot non quasdam tales, quales adversus Deum, fingere potuisse sic lilam doleamus insipientiam, ut miremur audaciam".

89. De civitate De1 IV 26,34-35, CCL 47,120:"In 111is ludis corruptorem pudicitiae Jovem turpissimi histriones cantabant, agebant,placebant": IV 27,42-43, CCL 47,121-122: "Jovem 1nterpolles... quia olus plura crimina ludis scaenicis actitantur" Sipistola 91,5, CSEL 34,430: ". ctot locis ping1tur...1egitur agitur cantatur saltatur Juppiter adulteria tanta committens .. cum haoc histriones agunt et saltant".

90 Confessiones III $3-4$, CSEL $33,46: " .$. sed tunc in theatris congaudebam amantibus, cum sese fruebantur per flagitia, quamvis haec imaginarie gererent in ludo spectacul1, cum autem sese amittebant, quasi misericors contristabar; et utrumque delectabat tamen... Ego tunc miser dolere amabam et quaerebam ut essel quod dolerein, quando mini in aerumna aliena ot falsa et saltatoria ea magis placebat actio histrionis meque alli- 
nie były czymś Innym, jak stwierdza W.Weismann9l, niź pantomimicznymi przedstawieniami mitologicznych lub opisanych $w$ itteraturze tragicznych miłości, a mianowicie oplewanej w IV ksiedze "Eneldy" Wergilego tragicznej miłości Dydony 1 Eneasza oraz Leandra 1 Her 8 ? Do Innych przedstawianych przez pantomime, a wspominanych przez Biskupa Hippony wówczas tematów należały: zejścle Eneasza do podziemi ${ }^{93}$, kradzleze Merkurego 1 cudzołóstwa Wenery ${ }^{94}$, sąd Parysa95, ukazywana plastycznie podczas Megalens16w tesknota Kybel1 płaczacej za umiłowanym Attysem ${ }^{96}$. R6wniez owa zagadkowa ułozona przez Augustyna "carmen theatricum" miała być zdaniem niektórych autorów kantykiem napisanym dla pantominicznego chóru ${ }^{97}$.

ciebat vehementius, qua mihi lacrimae excutiebantur".

91 K1rche und Schausp1ele, dzecyt. 127.

92 Confessiones I 20-22, CSEL 33, 18-20; por. Macrobius, Saturae V 17,5:". .. ut Pabula lascivientis Didonis... nistrionum perpetuis et gestibus et cantibus celebretur"; Fronto, Epistolae III 14/Van den Hout/: "Unde displicet mihi fabula histrionibus celebrata, ubi amans amantem puella iuvenem nocte lumine accenso stans in turri natantem in mare opperitur".

93 Sermo 241,5, PL 38,1136:"Exhorru1t quidam auctor 1psorum... qui inducebat apud inferos demonstrantem patrem filio suo. Nostis enim hoc prope omnes... pauci nostis in libris, multi in theatris, quia Aeneas descendit ad inferos ot ostendit 1111 pater suus animas Romanorum magnorum venturas in corpora"/Aeneid.VI 719-720/.

94 De civitate DeI VII 26,26-28, CCL 47,208: "Quid sunt ad hoc malum furta Mercuril, Veneris lascivia, stupra ac turpitudines ceterorum.!..nisi cotidie cantarentur et saltarentur in theatris".

95 De civitate De1 XVIII 10,16-21, CCL 48,601:"... 111ud quod de tribus deabus Junone scilicet et Minerva et Venere, quae pro malo aureo adipiscendo apud judicem Paridem de puichritudinis excellentia certasse narratur et ad placandos ludis deos... Inter theatricos plausus cantantur atque saltantur"; por. Tertullianus, Apologeticus 15,2; Apuleius, Metamorphoseos $\mathrm{X} 30$.

96 De civitate De1 II 4,14, CCL 47,37; por. Tertullianus, Ad nationes I 10,45 1 47; Lactant1us, Divinae Institutiones $V$ 10,16; Arnobius, Adversus nationes IV 35 i VII 33 .

97 Np. G.Boissier, De la signification des mots saltare et cantare tragoodiam, art.cyt. oraz W.Welsmann, dz•cyt.,129. 
Jeszcze mniej informacji przekazal nam Biskup Hippony o prezentowanym wówozas na scenie mimie. Powodem tego mógl byé m.in. I ten lakt, ze tego rodzaju przclstawienla przeznaczone byzy przede wszystkim dla ludzi prostych i niewykształconych, on zas naleząc do wyższej elity intelektualnej rzadziej zapewne je ogiądał. Mim był pochodna komedi1, a zwłaszcza, jak stwierdza Marek Aureliusz, komed11 nowej98. Do jego zasadniczych strukturalnych elementów nalezały: taniec wykonywany przez występujących bez masek i koturnów aktorów lub często na pólobnazone tancerki, śpiewane przez nie piosenki o treści erotycznej lub mitologicznej, złozony z męskich 1 kobiecych głosów chór śpiewający w towarzystwie muzyki instrumentalnej/ plety, oboje, cytry, cymbały, syringi/ partie liryczne, oraz wyrażający fabulę sztuki mcześnłej przez mimografa naplsany lub dorywczo improwizowany tekst w prozie lub poezji. W zależności od prezentowanej tematyki rozróżiano: mim blologlczny parodiujący wybrane sceny z zycia codziennego/ postępowanie skapców, pasożytów, głupców, zarłoków, zachowanie sie łysych, karłów, starców, prostytutek, zdradzonych naiwnych męzów, miłosne przygody Jowisza lub innych bogów/, mim mitologiczny parodiujacy wybrane sceny z mitologil/szczególnie wątk1 erotyczne lub tchnące okrucieństwem sceny/, mim prezentowany na zaproszenie po domach, mim chrystologiczny parodiujacy misteria chrześcijańskie/ chrzest, oucharystię, gesty liturgiczne,mczęństwo/ oraz mim wodny/totimim/ ukazujący nimfy 1 bóstwa morskie przez obnażonych aktorów 1 aktork1 wpecjalnych basenach. Gł6́wnym celem tego rodzaju przedstawień było wywołanto śmiechu 1 oddziaływante na zmysły widzów przez odpowiednio dobrane sceny $1 \mathrm{kom} 1 \mathrm{zm} / \mathrm{mimica}$ scurrilitas/99.

98 Meditationes XI 6, tłum,M_Re1ter/Marek Aureliusz, Rozmyślam nia, Warszawa 1958/,132: "Czym jest następujęca z kolei komedia średnia $i$ po co tez potem wprowadzono komedie nową która

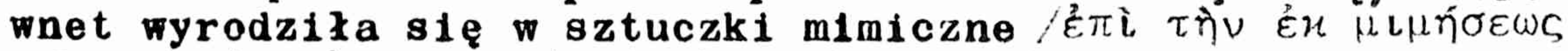

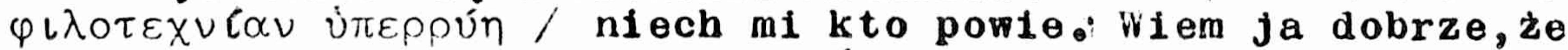
w niej napotyka się niejedną myśl pożyteczną, ale jaki jest

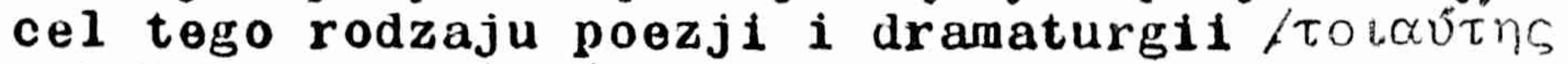

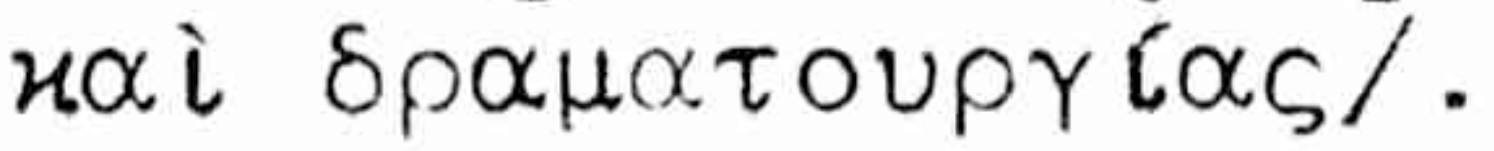

99 Por. M.Bonaria, Mitmorum Romanorum fragmenta, Pasc $1-2$, Genova 1955; II.Reich, Der Mimus, Bd.1-2,Berlin 1903;E.Wtst, Mimos, RE XV/2 1727-1764; A。F., Mimo, Enciclopedia dello spettacolo, VII, Foma 1060,598-613; H.Wiemken, Der griechische Mimus, Bremen 1972; 0.Pasquato,Gli spettacoli in S.Giovanni Crisostomo,dz•cyt.,97-136; G.J.Theocharidis, Beitrage zur Geschichte des byzantinisches profantheaters, dz॰cyt $t_{9} 67-111$. 
Mimo duzej niechęc1 do tego rodzaju przedstawien teatralnych, Augustyn uży kilkakrotnie terminu "mimus", zarónno na oznaczenie gatunku dramatycznego ${ }^{100}$, stawiając go $z$ tragedia 1 komedia jako owoc Itkcji poetyckiejlol, jak 1 na oznaczenie odgrywajacego go aktor ${ }^{102}$, choć trudno niekledy odróźnić, czy chodzi o pierwszy czy drugi wypadek, bo łacina ma dla obydwu jedna 1 ta sama nazwe. Biskup Hippony zdaje sie znać, być moze jeszcze ze szkoły, powtarzana przez starozytnych gramatykow definicje mimulo3, skoro uwiktane w róne problemy zycle ludzk1o porównuje waśnie do niego wołając:"Agamus ot nos mimum nostrum! Mimus est enlm generis humani tota vita tentation18 ${ }^{104}$. Sw1 adom jest takze, podobnie jak Inni jego chrześcijarscy poprzednicy ${ }^{105}$, istotnej cechy mimu - jego rubaszności, dowc1pu 1 komizmu/mimica scurrilitas/106, jak rómniez bezwstydu

100 Enarrationes in Psalmum 30 II $8.3,11,10$, CCL 38, 221: "Cu1 dico, ut diligat Dominum, qui adhuc diligit mimum, qui adduc diligit pantomimum"y Sermo Denis 17,7, MA I 87: "Quando leguatur passiones martyrum, specta.... Tu specta mimum, specta pantomimum"; De baptismo VII 101, CSEL 51,372, 24: "1 ocans sicut in mimo"; De civitate DeI VI 1,30, CCL 47,165:"qual1s localiter in mimo fleri solet".

101 Sol11oquia II 10,18, PL 32,893: "Itaque 1psa opera hominum velut comoedias aut comoedias aut mimos et id genus alla possumus operibus pictorum fictorumque coniungere".

102 Sermo 198,3, PL 38, 1026: "L1tes et contentiones usque ad inimicitias suscipiunt pro mimo, pro hisirione, pro pantomimo"; De o1vitate Dei II 26,37, CCL 47,62: "non 1bi pudibundos m1mos nullam verecundiorem scaentcam"; Sermo Den1s 17,7, MLA I 87: "Et fortassis ad talla commercia hunc veniant peregrini ot dic1tur: Quid quaris? Mimos meretrices?; De civitate Del VI 7,11 1 28-29 158 i 61, CCL 47,174-175: "Numquid Priapo miml, non etiam sacerdotes enormia pudenda fecerunt... quid aliud quam mimica sacra esse voluerunt... si mimus dixissot ......Haec 81 poetae fingerent, si mimi agerent... non mimorum sed sacrorum".

103 Por. Diomedes, Ars grammatica III p.45E.56C/ed.Ke11 s.491/: "mim jest naśladowaniem zycia, zarowno rzeczy dozwnlonych jak 1 zakazanych"; Choricius, Apologia mimi 89, ed.R.Foerster-E.Rlchstoig, Leipzig 1929,364: "Tu tez lezy uzasadnienie tej nazwy, która jak mów1ą, przylgnęła do nich dlatego, ze staraja sie odtwarzać zycie".

104 Enarrationes in Psalmum 127,15,39-40, CCL 40,1878.

105 Por: Novatianus, De spectaculis 6,1, CCL 4,174/8curriles $10008 /$; Arnobius, Adversus nationes IV 36, CSEL $4,170 / \mathrm{mimis}$ et scurrilibus ludicris sanctissimorum personae/.

106 In Joannem tractatus 97,3,13, CCL 36,574:"Utinam tales quales in theatris sive cantantur... sive mimica scurrilitate ridentur"; De civitate DeI VI 1,45,CCL 47,165:"ut mimioae 
wsṕfłczesnych mu 1 krytykowanych od lat przedstawleń mimicznych /mimica turpitudo/107, których aktorki, tak jak 1 inni ojcowie Kościoła, nazywa wprost "meretricesnl08 Ponadto z istotnych składników mimu zdaje sie wspominać jego piosenki/cantica/109 oraz mimiczny chór ${ }^{110}$, z jego zaś gatunków - mim chrystologiczny parodiujacy chrzest 111. Nie wiadomo, czy z ogladania, czy ze słyszenia wiedzial tez, ze podczas tego rodzaju przedstawień prezentowane sa równiez miłosne przygody bogów/ szczególnie Jowisza/, 1ch czcze obrzedy, zachowante sie 1 obzarstwo ${ }^{112}$. N1e wiadomo, wakiej mierze Augustyn oglądaz mimy $w$ teatrze, z cała pewnościa natomiast oglądał Je, jak sam wyznaje, podczas floralión 1 śvieta kartagińskiej bogini Celeste, kledy to aktorki na żqdanie widzów rozbierazy sle nawet do naga 1 spełniały różnorodne ich zyczenia 113

Z przedstawionych wyzej uwag wynika, ze znajomość dramatu klasycznego u św. Augustyna była raczej powlerzchowna 1 ograniczala się głównie do wladomośc1, jakie zdobył w rymskiej szkole 1 podczas swej retorycznej pracy przed nawrócentem. Jeszcze mniej konkretnych informacj1 przekazał nam na temat wystawlanych porszechnie w jego czasach w teatrach pantomimle 1 mimle. Znat je zapewne, ale nie chcial sie na lch temat teoretycznie wypowiadac ograniczajac sie jedynie do pietnowania lch niemoralnej treści.

Clag dalszy nastepnym zeszycle.

Ks. Stanisław Longosz - Lublin

107 Por. Quodvultdeus, Sermo de Symbolo I 4,15, CCL 60,308: "Illic per mimicam turpitudinem castitas violatur".

108 De civitate De1 VII 21,21, CCL 47,203:"...quod nec meretrix permitti debuit in theatro".

109 Enarrationes in Psalmum 84,15,29, CCL 39,1175:"cåntica nugatoria ot adulterina".

110 De civitate De1 VI 7,90,CCL 47,176:"1n choro meretricum".

111 i) baptismo VII 101, CSLL 51,372-373:"iocans sicut in mimo ....inter agendum repentina pietate moveatur... qui fideliter subito commotus acoipiat/baptismum/...religione mutatus est".

112 De civitate Dei VI 7,CCL 47,174-176; VI 1,29-31,CCL 47,165.

113 De civitate De1 If 26,37-38, CCL 47,62:"non tb1 pudibundos mimos nullam verecundiorem scaentcam vidimus". 
QUID S. AUGUSTINUS DE ANTIQUO DILAMATI THEATRALI SENSERIT ?

\section{/ Argumentum/}

Dissertatiuncula tribus partibus constat. E parte prima, quae hoc in fasciculo invenitur, patet, quae $S$. Augustinus in operibus suis de antiquo dranati theatrali, 1d est de tragoedia, comoedia, pantomimo ac mimo scripserit. Enumerantur quoque omnia loca, in quibus sententiae antiquorum tragicorum atque comicorum allatae sunt. Hac in re eminentissimum locum Terentius comicus occupat. 